\title{
Biphasic Forearm Vascular Responses to Intraarterial Arginine Vasopressin
}

\author{
Satoshi Suzuki, Akira Takeshita, Tsutomu Imaizumi, Yoshitaka Hirooka, Megumu Yoshida, \\ Shinichi Ando, and Motoomi Nakamura \\ Research Institute of Angiocardiology and Cardiovascular Clinic, Faculty of Medicine, Kyushu University, Fukuoka 812, Japan
}

\begin{abstract}
Forearm vascular responses to arginine vasopressin (AVP) infused into a brachial artery in a wide range of infusion rates (0.05-2.0 $\mathrm{ng} / \mathrm{kg}$ per min) were examined in 20 young healthy volunteers. Intraarterial AVP at lower doses (0.05 and 0.1 $\mathrm{ng} / \mathrm{kg}$ per min) caused forearm vasoconstriction, whereas AVP at a dose of $0.2 \mathrm{ng} / \mathrm{kg}$ per min or higher caused forearm vasodilatation. The maximal forearm vasoconstriction was induced at the venous plasma AVP level of $76.3 \pm 8.8 \mathrm{pg} / \mathrm{ml}$. Forearm vasodilatation was associated with the venous plasma AVP level of $369 \pm 43 \mathrm{pg} / \mathrm{ml}$ or higher. Forearm vasodilatation was the result of the direct effect of AVP since forearm blood flow and vascular resistance in the contralateral arm did not change. We attempted to explore the mechanisms involved in AVP-induced direct vasodilatation. The treatment with indomethacin, $75 \mathrm{mg} / \mathrm{d}$ for $3 \mathrm{~d}$, did not alter AVP-induced forearm vasodilatation. In contrast, intraarterial infusion of isoosmolar $\mathrm{CaCl}_{2}$ totally prevented AVP-induced forearm vasodilatation. Intraarterial $\mathrm{CaCl}_{2}$ also markedly attenuated forearm vasodilatation induced by intraarterial sodium nitroprusside, but did not alter forearm vasodilatation induced by intraarterial isoproterenol. These results indicate that the direct vascular effects of intraarterial AVP on the forearm vessels are biphasic, causing vasoconstriction at lower doses and vasodilatation at higher doses. The direct vasodilatation induced by intraarterial AVP at higher doses is not mediated by prostaglandins but may involve cGMP-related mechanisms.
\end{abstract}

\section{Introduction}

Arginine vasopressin (AVP) ${ }^{1}$ is a potent vasoconstrictor agent in vitro (1). However, AVP does not produce the expected rise in blood pressure or vascular resistance when given intravenously to intact animals $(2,3)$ or humans (4). Other studies in humans have shown that intravenous AVP at a high dose causes a small transient increase in blood pressure or total peripheral vascular resistance, which returns to the control value despite continued infusion $(5,6)$. Furthermore, it has

Address reprint requests to Dr. Akira Takeshita, Research Institute of Angiocardiology and Cardiovascular Clinic, Faculty of Medicine, Kyushu University, 3-1-1 Maidashi, Higashiku, Fukuoka 812, Japan.

Received for publication 7 September 1988 and in revised form 3 February 1989.

1. Abbreviations used in this paper: ANOVA, analysis of variance; AVP, arginine vasopressin; EDRF, endothelium-derived relaxant factor.

\section{J. Clin. Invest.}

(c) The American Society for Clinical Investigation, Inc.

0021-9738/89/08/0427/08 $\$ 2.00$

Volume 84, August 1989, 427-434 been shown that intravenous AVP at a high dose may even produce forearm vasodilatation in humans $(4,7,8)$.

To explain the difference in the vasoconstrictor effect of AVP between in vivo and in vitro studies, it has been suggested that AVP facilitates baroreflex mechanisms, such that the direct vasoconstrictor effect of AVP is countered by a reflex reduction in heart rate, cardiac output, and peripheral vascular resistance $(3,5,7,9-11)$. However, recent studies in animals have suggested that AVP may induce direct vasodilatation by activating vasodilatory mechanisms in blood vessels. Oliver et al. and Seino et al. have suggested that intraarterial infusion of AVP into the renal artery may cause vasodilatation by augmenting the synthesis of vasodilatory prostaglandins $(12,13)$. Others have suggested that AVP may activate endotheliumdependent vasodilatation (14) or produce vasodilatation by stimulating the V2 receptors in blood vessels (15-17). These results raise the possibility that activated vasodilatory mechanisms may buffer the direct vasoconstrictor effect of AVP. However, whether these vasodilatory mechanisms play a role in control of circulation by AVP in humans is not known.

A few studies have examined the direct vascular effect of AVP in humans by infusing AVP intraarterially $(4,18)$. The results are conflicting with one study reporting vasoconstriction (4) and the other vasodilatation (18). Thus, the purpose of this study was to assess the direct vascular effect of AVP in humans. We examined forearm vascular responses to AVP infused into a brachial artery in a wide range of infusion rates and correlated vascular responses with the venous plasma AVP levels. In addition, we attempted to explore the mechanisms involved in forearm vasodilatation caused by intraarterial AVP at high doses.

\section{Methods}

Subjects. Studies were performed in 20 young healthy volunteers (mean age, $21.1 \pm 0.4 \mathrm{yr}$; mean body weight, $60.9 \pm 1.7 \mathrm{~kg}$, mean $\pm \mathrm{SE}$ ). All subjects were male. The study protocol was explained, and informed consent was obtained from each subject.

Measurements of forearm blood flow, arterial pressure, and heart rate. Forearm blood flow was measured using a mercury-in-silastic strain gauge plethysmograph with the venous occlusion technique (19, 20). The strain gauge was placed $\sim 5 \mathrm{~cm}$ below the antecubital crease. The pressure in the venous occlusion or congesting cuff was $40 \mathrm{mmHg}$. Circulation to the hand was arrested by inflating a cuff around the wrist until pressure was suprasystolic during determination of forearm blood flow. Forearm blood flow was taken as the average of four to eight flow measurements made at 15 -s intervals. Calculation of forearm blood flow was performed independently by two of the authors, and the average value was used for statistical analysis. Blood pressure was measured by a sphygmomanometer in the other arm. All blood pressure measurements were performed by one individual to minimize observer variation. Forearm vascular resistance was calculated by dividing mean arterial pressure (diastolic pressure plus one-third of the pulse pressure in $\mathrm{mmHg}$ ) by forearm blood flow $(\mathrm{ml} / \mathrm{min}$ per $100 \mathrm{ml}$ of forearm volume); these values are expressed as units throughout this 
report. Heart rate was determined by counting radial pulse for a minute.

Forearm vascular responses to AVP. A brachial artery was cannulated with a 20-gauge intravascular over-the-needle Teflon catheter (Quick-cath; Travenol-Genentech Laboratories, Cambridge, MA) for drug infusion and a vein in the antecubital region of the same arm was cannulated to obtain blood samples for the measurements of plasma levels of AVP, cAMP, cGMP, and ionized calcium. After the placement of cannulae and a strain gauge plethysmograph, at least $15 \mathrm{~min}$ were allowed for the subjects to become accustomed to the study conditions before beginning the experiments. The arterial line was kept open by infusion of heparinized saline before drug infusion.

In six subjects, the dose-dependent effects of intraarterial AVP on forearm circulation were examined. AVP at rates of 0.05, 0.1, 0.2, 0.5, and $1.0 \mathrm{ng} / \mathrm{kg}$ per min were infused intraarterially for $2 \mathrm{~min}$ at each dose. Forearm blood flow was measured continuously in the ipsilateral arm during drug infusion. The volumes of infusion were $0.1,0.2$, and $0.4 \mathrm{ml} / \mathrm{min}$ for infusion rates of $0.05,0.1$, and $0.2 \mathrm{ng} / \mathrm{kg}$ per min, respectively, and 0.1 and $0.2 \mathrm{ml} / \mathrm{min}$ for infusion rates of 0.5 and 1.0 $\mathrm{ng} / \mathrm{kg}$ per min, respectively.

In seven subjects, we attempted to explore the mechanisms whereby intraarterial AVP at higher doses produced forearm vasodilatation in healthy men. In these subjects, AVP at rates of 1.0 and 2.0 $\mathrm{ng} / \mathrm{kg}$ per min were infused intraarterially. The volumes of infusion were 0.2 and $0.4 \mathrm{ml} / \mathrm{min}$.

First, to exclude the possibility that the vasodilator effects of intraarterial AVP at higher doses might be mediated by the systemic neural effects $(7,8)$, we measured forearm blood flow simultaneously in the contralateral and ipsilateral arms during intraarterial infusions of AVP $(n=5)$.

Second, previous studies in humans and animals have suggested that AVP stimulates endogenous prostaglandin synthesis in blood vessels as well as in kidney $(12,21-25)$. To examine the possibility that this mechanism might have contributed to vasodilatation, we studied forearm vascular responses to intraarterial AVP before and after the treatment with oral indomethacin at a dose of $75 \mathrm{mg} / \mathrm{d}$ for $3 \mathrm{~d}$ in the same subjects $(n=5)$.

Third, we examined the effect of increased plasma ionized calcium on forearm vascular responses to intraarterial $\operatorname{AVP}(n=6)$. This study was done because a recent study in humans suggested that vasodilatation mediated by cGMP may be markedly attenuated by increased plasma-ionized calcium (26). After the study with intraarterial infusion of AVP alone was completed, we began saline infusion and waited for at least $10 \mathrm{~min}$, by which time forearm blood flow returned to the baseline value. Then, we started intraarterial infusion of isoosmolar calcium chloride at a dose of $0.09 \mathrm{meq} / \mathrm{min}$ in a volume of $0.2 \mathrm{ml} / \mathrm{min}$. Calcium chloride was infused for $10 \mathrm{~min}$ and then we began simultaneous intraarterial infusions of calcium chloride and AVP at two doses. The volumes of infusion during simultaneous infusions of the two drugs were 0.4 and $0.6 \mathrm{ml} / \mathrm{min}$. We confirmed that the increase in the volume of infusion by itself did not alter forearm blood flow.

Forearm vascular responses to sodium nitroprusside or isoproterenol. We also examined the effect of increased plasma-ionized calcium on forearm vasodilatation caused by intraarterial sodium nitroprusside or isoproterenol. The experiments were done in the same way as the study with AVP. First, forearm blood flow was measured during intraarterial infusion of sodium nitroprusside at doses of $1.7,3.3$, and 6.7 $\mathrm{ng} / \mathrm{kg}$ per $\min (n=3)$ or isoproterenol at doses of $0.08,0.17$, and 0.33 $\mathrm{ng} / \mathrm{kg}$ per $\min (n=4)$. Then, the measurements of forearm blood flow were repeated during simultaneous infusions of calcium chloride at a dose of $0.09 \mathrm{meq} / \mathrm{min}$ and sodium nitroprusside at three doses $(n=3)$ or isoproterenol at three doses $(n=4)$. The volumes of intraarterial infusion of sodium nitroprusside or isoproterenol were $0.1,0.2$, and $0.4 \mathrm{ml} / \mathrm{min}$, and the volume of calcium chloride infusion was 0.2 $\mathrm{ml} / \mathrm{min}$.

Preparation of AVP, sodium nitroprusside, and isoproterenol. 20 pressor units/ml synthetic AVP (Pitressin; Parke-Davis, Inc., Morris Plains, NJ) was diluted in physiological saline to a concentration of 30 or $300 \mathrm{ng} / \mathrm{ml}$. Sodium nitroprusside (Wakou Junyaku Kougyou, Osaka, Japan), was dissolved in physiological saline at a concentration of $1,000 \mathrm{ng} / \mathrm{ml}$. Special care was taken not to expose nitroprusside to light. Isoproterenol (Proterenol-L; Nikken Kagaku, Tokyo, Japan), 0.2 $\mathrm{mg} / \mathrm{ml}$, was diluted in physiological saline to a concentration of 50 $\mathrm{ng} / \mathrm{ml}$.

Plasma levels of AVP, cAMP, cGMP, and ionized calcium. The plasma AVP levels in the venous effluents were determined during intraarterial infusion of saline and AVP at each dose. The venous plasma cAMP and cGMP levels were determined during infusion of saline and the maximal dose of AVP $(2.0 \mathrm{ng} / \mathrm{kg}$ per min), sodium nitroprusside $(6.7 \mathrm{ng} / \mathrm{kg}$ per $\mathrm{min})$ or isoproterenol $(0.33 \mathrm{ng} / \mathrm{kg}$ per $\mathrm{min})$. Venous blood for the measurements of AVP, cAMP and cGMP were sampled into the tube containing EDTA-2K $(1 \mathrm{mg} / \mathrm{ml})$. Plasma AVP was measured in duplicate by RIA using RIA kits obtained from Mitsubishi Petrochemical Co. Ltd. (Tokyo, Japan), after Sep-Pak C18 extraction of plasma as previously described $(27,28)$. Plasma cAMP and cyclic GMP were measured in duplicate by RIA using RIA kits obtained from Yamasa Shoyu Co. (Tokyo, Japan) after succinylation as previously described (29). All measurements by RIA were performed in the laboratory of Bio-Medical Laboratories Co. (Tokyo, Japan). We also determined venous plasma ionized calcium by an autoanalyzer (Nova-2; Nova Biomedical Corp., Waltham, MA) during intraarterial infusion of saline and calcium chloride.

Statistical analysis. Statistical analysis of forearm vascular responses to intraarterial AVP, sodium nitroprusside or isoproterenol was performed with the use of a one-way analysis of variance (ANOVA). The Newman-Keuls multiple comparisons test was used to determine the level of statistical significance comparing the value at control with that at each dose of the drugs (30). Two-way ANOVA was used to compare forearm vascular responses to AVP before indomethacin with those after indomethacin, and to compare responses to the drug alone with those to simultaneous infusion of the drug and calcium chloride. Paired $t$ test was used to compare plasma concentrations of AVP, cAMP, cGMP and ionized calcium between saline and drug infusion.

All values are expressed as means \pm SE and $P \leqq 0.05$ was considered to be statistically significant.

\section{Results}

Responses to AVP (Table I and Table II). Intraarterial infusions of AVP at graded doses into a brachial artery did not alter mean blood pressure or heart rate. Forearm vascular responses to intraarterial AVP were biphasic. AVP at a dose of 0.05 $\mathrm{ng} / \mathrm{kg}$ per min decreased forearm blood flow $(P<0.05)$ and AVP at doses of 0.05 and $0.1 \mathrm{ng} / \mathrm{kg}$ per min increased forearm vascular resistance $(P<0.01$ and $P<0.05$, respectively), whereas AVP at a dose of $0.2 \mathrm{ng} / \mathrm{kg}$ per min and higher increased forearm blood flow and decreased forearm vascular resistance $(P \leqq 0.05$ for $0.2 \mathrm{ng} / \mathrm{kg}$ per min and $P<0.01$ for higher doses). Representative plethysmographic recordings of forearm blood flows during intraarterial infusions of AVP at graded doses are shown in Fig. 1. Percent changes in forearm vascular resistance induced by intraarterial AVP at graded doses are shown in Fig. 2.

The relationship between plasma AVP levels and percent changes in forearm vascular resistance in each subject is shown in Fig. 3. The venous plasma AVP levels increased in a dosedependent fashion $(P<0.01)$. The venous plasma AVP level that caused the maximal forearm vasoconstriction in an individual subject was $76.3 \pm 8.8 \mathrm{pg} / \mathrm{ml}$. Forearm vascular resistance returned toward the control value or decreased as the venous plasma AVP levels were between 100 and $400 \mathrm{pg} / \mathrm{ml}$, and forearm vasodilatation was induced in all subjects when 
Table I. Forearm Vascular Responses to Intraarterial Infusion of AVP at Graded Doses $(n=6)$

\begin{tabular}{|c|c|c|c|c|c|c|c|}
\hline & Control* & $\operatorname{AVP}(0.05)$ & $\operatorname{AVP}(0.1)$ & $\operatorname{AVP}(0.2)$ & $\operatorname{AVP}(0.5)$ & $\operatorname{AVP}(1.0)$ & $\begin{array}{c}P \text { value by } \\
\text { one-way ANOVA }\end{array}$ \\
\hline & \multicolumn{7}{|c|}{ ng/kg per min } \\
\hline Mean blood pressure $(\mathrm{mmHg})$ & $80.3 \pm 3.3$ & $80.5 \pm 3.3$ & $80.3 \pm 3.2$ & $80.7 \pm 3.7$ & $81.1 \pm 3.1$ & $81.4 \pm 3.1$ & NS \\
\hline Heart rate $(b p m)^{\S}$ & $60.0 \pm 2.0$ & $60.3 \pm 1.6$ & $60.3 \pm 1.5$ & $62.0 \pm 2.2$ & $61.0 \pm 2.6$ & $61.0 \pm 1.2$ & NS \\
\hline Forearm blood flow ( $\mathrm{ml} / 100 \mathrm{ml} \mathrm{per} \mathrm{min)}$ & $5.2 \pm 0.4$ & $3.4 \pm 0.3^{\prime \prime}$ & $4.4 \pm 0.5$ & $7.1 \pm 0.9^{\|}$ & $8.2 \pm 0.8^{9}$ & $10.1 \pm 0.9^{1}$ & $P<0.01$ \\
\hline Forearm vascular resistance (units) & $16.0 \pm 1.6$ & $24.8 \pm 2.0^{\prime}$ & $20.4 \pm 2.9^{\| \prime}$ & $12.5 \pm 1.6^{\prime \prime}$ & $10.5 \pm 1.2^{4}$ & $8.4 \pm 0.9^{1}$ & $P<0.01$ \\
\hline
\end{tabular}

* Control, during infusion of saline; ${ }^{\ddagger}$ ANOVA, analysis of variance; ${ }^{\S}$ beats per minute; ${ }^{\prime} P<0.05$ vs. control value; ${ }^{\top} P<0.01$ vs. control value.

the venous plasma AVP levels were $>400 \mathrm{pg} / \mathrm{ml}$. The lowest venous plasma level associated with forearm vasodilatation in an individual subject was $369 \pm 43 \mathrm{pg} / \mathrm{ml}$.

Forearm blood flow and forearm vascular resistance in the contralateral arm did not change during intraarterial infusions of AVP at doses of 1.0 and $2.0 \mathrm{ng} / \mathrm{kg}$ per min, which caused forearm vasodilatation in the ipsilateral arm.

The treatment with indomethacin for $3 \mathrm{~d}$ did not significantly alter baseline mean blood pressure, heart rate, forearm blood flow, or forearm vascular resistance. Intraarterial infusions of AVP at doses of 1.0 and $2.0 \mathrm{ng} / \mathrm{kg}$ per min after the treatment with indomethacin increased forearm blood flow $(P$ $<0.01)$ and decreased forearm vascular resistance $(P<0.01)$ in a dose-dependent fashion. The magnitudes of vasodilating responses to AVP did not differ before and after the treatment with indomethacin (Fig. 4).

Intraarterial infusion of calcium chloride did not alter baseline mean blood pressure, heart rate, forearm blood flow, or forearm vascular resistance. However, simultaneous intraarterial infusion of calcium chloride totally inhibited vasodi- lating responses to AVP at doses of 1.0 and $2.0 \mathrm{ng} / \mathrm{kg}$ per min (Fig. 4). Plasma ionized calcium of the venous effluent increased from $1.14 \pm 0.06 \mathrm{mM}$ during saline infusion to $1.45 \pm 0.04 \mathrm{mM}$ during infusion of calcium chloride $(P<0.01)$. Plasma levels of cGMP and cAMP did not change during intraarterial infusion of AVP at the dose of $2.0 \mathrm{ng} / \mathrm{kg}$ per min (cGMP $4.7 \pm 0.6 \mathrm{pmol} / \mathrm{ml}$; cAMP $17.6 \pm 0.6 \mathrm{pmol} / \mathrm{ml}$ ) as compared to those during saline infusion (cGMP $4.6 \pm 0.6 \mathrm{pmol} /$ $\mathrm{ml}$; cAMP $15.9 \pm 1.0 \mathrm{pmol} / \mathrm{ml}$, NS for both).

Responses to sodium nitroprusside or isoproterenol (Table III and Table IV). Intraarterial infusions of sodium nitroprusside or isoproterenol at graded doses did not alter mean blood pressure or heart rate. Intraarterial infusion of sodium nitroprusside or isoproterenol increased forearm blood flow $(P$ $<0.05$ for sodium nitroprusside and $P<0.01$ for isoproterenol) and decreased forearm vascular resistance $(P<0.01$ for both) in a dose-dependent fashion. The magnitudes of vasodilating responses to these two drugs were comparable. Intraarterial infusion of calcium chloride did not significantly alter baseline blood pressure, heart rate, forearm blood flow, or

Table II. Forearm Vascular Responses to Intraarterial Infusion of AVP at Higher Doses

\begin{tabular}{|c|c|c|c|c|}
\hline & Control* ${ }^{*}$ & $\operatorname{AVP}(1.0)$ & AVP (2.0) & $\begin{array}{c}P \text { value by } \\
\text { one-way ANOVA }\end{array}$ \\
\hline & \multicolumn{4}{|c|}{$n g / k g$ per min } \\
\hline \multicolumn{5}{|l|}{ (1) Ipsilateral forearm $(n=7)$} \\
\hline Mean blood pressure $(\mathrm{mmHg})$ & $77.4 \pm 1.9$ & $78.5 \pm 2.2$ & $79.1 \pm 1.7$ & NS \\
\hline Heart rate $(b p m)$ & $65.7 \pm 3.6$ & $64.7 \pm 2.9$ & $64.3 \pm 3.2$ & NS \\
\hline $\mathrm{FBF}^{\ddagger}(\mathrm{ml} / 10 \mathrm{ml}$ per $\mathrm{min})$ & $3.9 \pm 0.5$ & $6.7 \pm 0.8^{\S}$ & $10.5 \pm 0.9^{\S}$ & $P<0.01$ \\
\hline FVR" (units) & $21.5 \pm 2.4$ & $12.9 \pm 1.6^{\S}$ & $8.1 \pm 0.9^{\S}$ & $P<0.01$ \\
\hline \multicolumn{5}{|l|}{ (2) Contralateral forearm $(n=6)$} \\
\hline FBF & $4.1 \pm 0.8$ & $3.9 \pm 0.6$ & $3.6 \pm 0.6$ & NS \\
\hline FVR & $22.3 \pm 3.3$ & $22.3 \pm 2.5$ & $24.3 \pm 3.3$ & NS \\
\hline \multicolumn{5}{|c|}{ (3) After treatment with indomethacin $(n=5)$} \\
\hline Mean blood pressure & $82.6 \pm 3.0$ & $84.4 \pm 3.3$ & $84.9 \pm 3.2$ & NS \\
\hline Heart rate & $59.6 \pm 2.9$ & $59.6 \pm 2.9$ & $59.6 \pm 2.9$ & NS \\
\hline FBF & $3.3 \pm 0.4$ & $6.1 \pm 1.0^{\prime}$ & $9.7 \pm 1.7^{\S}$ & $P<0.01$ \\
\hline FVR & $26.8 \pm 2.4$ & $16.2 \pm 2.9^{\S}$ & $10.7 \pm 2.3^{\S}$ & $P<0.01$ \\
\hline \multicolumn{5}{|c|}{ (4) During simultaneous infusion of calcium chloride $(n=6)$} \\
\hline Mean blood pressure & $78.8 \pm 1.6$ & $80.2 \pm 1.8$ & $81.0 \pm 1.7$ & NS \\
\hline Heart rate & $65.7 \pm 4.0$ & $62.7 \pm 2.6$ & $63.3 \pm 2.1$ & NS \\
\hline FBF & $3.7 \pm 0.4$ & $4.3 \pm 0.8$ & $4.7 \pm 0.8$ & NS \\
\hline FVR & $22.5 \pm 2.2$ & $22.0 \pm 3.0$ & $20.1 \pm 3.3$ & NS \\
\hline
\end{tabular}

\footnotetext{
* Control, during infusion of saline $\left(1,2\right.$, and 3) or during infusion of $\mathrm{CaCl}_{2}$ alone (4); ${ }^{\ddagger} \mathrm{FBF}$, forearm blood flow; ${ }^{\S} P<0.01$ vs. control value;
}

"FVR, forearm vascular resistance; $' P<0.05$ vs. control value. 


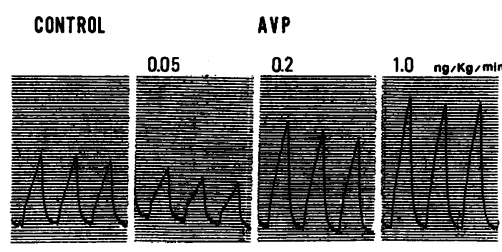

Figure 1. Representative recordings of forearm blood flow during intraarterial infusion of AVP at graded doses. Intraarterial AVP at a dose of $0.05 \mathrm{ng} / \mathrm{kg}$ per min decreased but in-

traarterial AVP at doses of 0.2 and $1.0 \mathrm{ng} / \mathrm{kg}$ per min increased forearm blood flow.

forearm vascular resistance. Simultaneous intraarterial infusion of calcium chloride significantly attenuated vasodilating responses to sodium nitroprusside $(P<0.01)$, whereas it did not alter vasodilating responses to isoproterenol (Fig. 5).

The plasma cGMP level in the venous effluent during infusion of sodium nitroprusside at the dose of $6.7 \mathrm{ng} / \mathrm{kg}$ per min $(4.4 \pm 0.8 \mathrm{pmol} / \mathrm{ml})$ did not differ from that during infusion of saline $(4.5 \pm 0.6 \mathrm{pmol} / \mathrm{ml})$. The plasma cAMP level in the venous effluent during infusion of isoproterenol at the dose of $0.33 \mathrm{ng} / \mathrm{kg}$ per min $(16.5 \pm 1.9 \mathrm{pmol} / \mathrm{ml})$ did not differ from that during infusion of saline $(19.7 \pm 2.5 \mathrm{pmol} / \mathrm{ml})$. Thus, sodium nitroprusside and isoproterenol failed to significantly increase plasma cyclic nucleotide levels although mediating vasodilation.

\section{Discussion}

The findings of this study allow three conclusions. First, AVP infused intraarterially at a dose of $0.2 \mathrm{ng} / \mathrm{kg}$ per min or higher exerts a direct vasodilator effect on forearm vessels in humans. In contrast, intraarterial AVP at lower doses causes forearm vasoconstriction. Second, the direct vasodilator effect of AVP at higher doses is not mediated by prostaglandins. Third, the vasodilator effect of AVP can be inhibited by an increase in plasma-ionized calcium. Forearm vasodilatation resulting from the direct effect of AVP on forearm vessels was an unanticipated finding in view of its known vasoconstrictor effect. Thus, in the Discussion, we will first consider how these observations relate to previous works in humans and, second, we

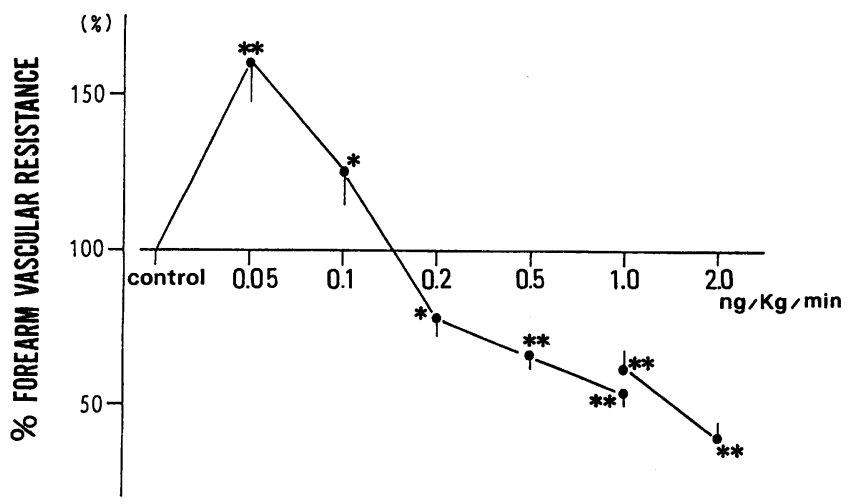

Figure 2. Percent changes in forearm vascular resistance induced by intraarterial AVP at graded doses. Forearm vascular responses to intraarterial AVP at rates of $0.05-1.0 \mathrm{ng} / \mathrm{kg}$ per min were studied in six subjects and those at rates of 1.0 and $2.0 \mathrm{ng} / \mathrm{kg}$ per min in seven subjects. * and ${ }^{* *}$ indicate $P \leqq 0.05$ and $P<0.01$ comparing with control value by use of the Newman-Keuls multiple comparisons test.

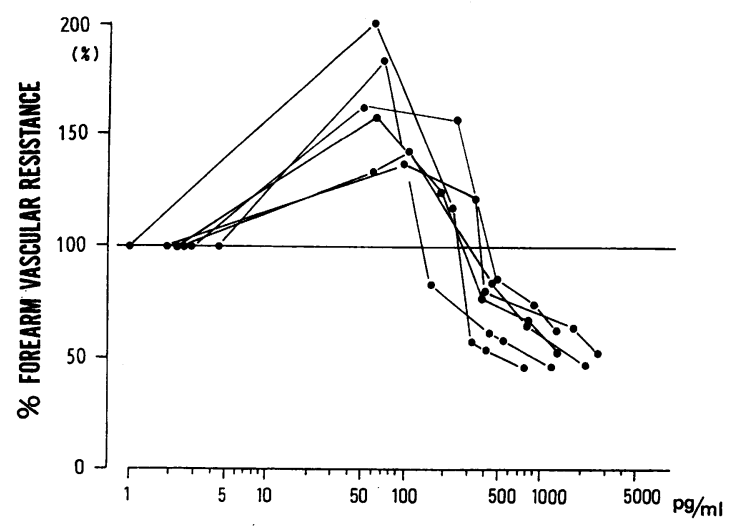

Figure 3. The relationship between percent changes in forearm vascular resistance and the venous plasma AVP level in each subject $(n=6)$.

will speculate on the mechanisms involved in the direct vasodilator effect of AVP.

AVP-induced vasodilatation in humans. Although AVP is a potent vasoconstrictor agent (1), AVP-induced vasodilatation has been observed in humans $(4,7,8,18)$ and in animals $(12$, 13). In humans, several groups of investigators have demonstrated that intravenous infusion of AVP may cause forearm vasodilatation after $>10$ min of intravenous infusion of AVP at a high dose ( $4 \mathrm{ng} / \mathrm{kg}$ per min or higher) $(4,7,8)$, which raised the plasma AVP level to $\sim 300 \mathrm{pg} / \mathrm{ml}(7,8)$. In contrast, it has been shown that a modest increase in the plasma AVP level to $<50 \mathrm{pg} / \mathrm{ml}$ caused by intravenous infusion of AVP at a low dose did not alter forearm vascular resistance (7) or produced vasoconstriction in muscle and skin $(31,32)$.

Aylward et al. and Floras et al. have suggested that forearm vasodilatation caused by intravenous AVP at a high dose may result from facilitation of reflex sympathetic withdrawal that competes with the direct vasoconstrictor effect of $\operatorname{AVP}(7,8)$. This suggestion was based on findings that intravenous AVP at a high dose augmented reflex forearm vasodilatation in response to the acute rise in central venous pressure (7) and inhibited muscle sympathetic nerve activity recorded from the peroneal nerve (8). This suggestion is supported by findings in animal studies that have shown that AVP augments reflex inhibition of sympathetic nerve activity mediated by arterial

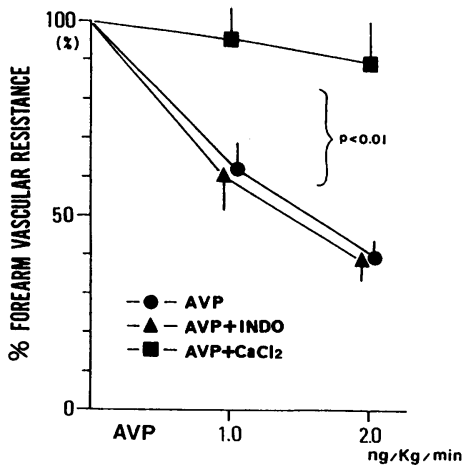

Figure 4. Percent changes in forearm vascular resistance induced by intraarterial AVP at rates of 1.0 and $2.0 \mathrm{ng} / \mathrm{kg}$ per min. $\bullet$, values during infusions of AVP alone (before indomethacin) (AVP) $(n=7)$; $\Delta$, values after the treatment with indomethacin $(\mathrm{AVP}+\mathrm{INDO})(n=5)$; and $\mathrm{m}$, values during simultaneous infusions of AVP and $\mathrm{CaCl}_{2}\left(\mathrm{AVP}+\mathrm{CaCl}_{2}\right)$ $(n=6)$. Responses to AVP were not different before and after indomethacin. Simultaneous infusion of $\mathrm{CaCl}_{2}$ attenuated forearm vascular responses to AVP ( $P$ $<0.01$ ). 
Table III. Forearm Vascular Responses to Intraarterial Infusion of Sodium Nitroprusside $(S N P)(n=3)$

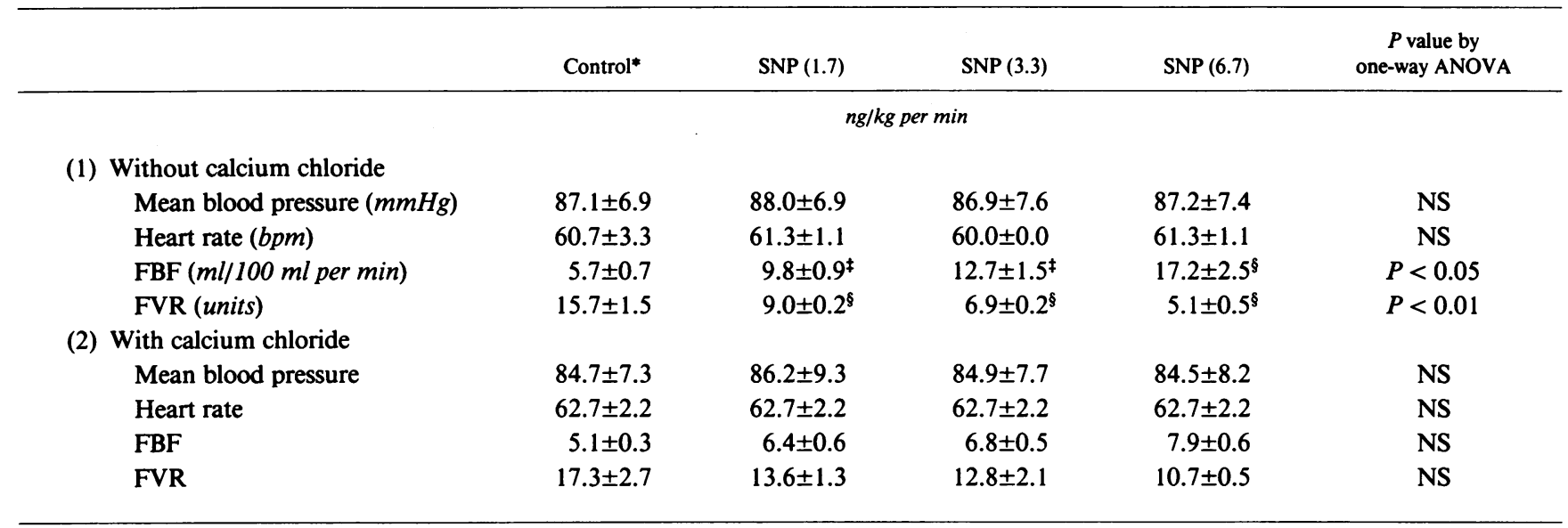

* Control, during infusion of saline (1) or during infusion of $\mathrm{CaCl}_{2}$ alone (2); ${ }^{\ddagger} P \leqq 0.05$ vs. control value; ${ }^{\S} P<0.01$ vs. control value.

and cardiopulmonary baroreceptors $(9,33-37)$. However, it appears that this mechanism does not totally account for forearm vasodilatation observed in humans during intravenous infusion of AVP at higher doses. Kitchin has shown that blocking of the deep nerves in the forearm by xylocaine did not prevent forearm vasodilatation caused by intravenous AVP (4). The effectiveness of nerve block was confirmed by the absence of sweating and the loss of voluntary movements (4).

Forearm vascular responses to intraarterial infusion of AVP also have been examined previously in humans $(4,18)$. Kitchin has shown that intraarterial AVP at a low dose (4.3 $\mathrm{ng} / \mathrm{min}$ ) caused forearm vasoconstriction (4). In contrast, a preliminary report by Hirsch et al. has indicated that intraarterial AVP at a very high dose (10 $\mathrm{ng} / \mathrm{kg}$ per min) induced forearm vasodilatation (18). The results of this study provide explanation for the difference between the two previous studies. We found that intraarterial AVP caused forearm vasoconstriction when infused at doses of 0.05 and $0.1 \mathrm{ng} / \mathrm{kg}$ per min but produced forearm vasodilatation when infused at a dose of 0.2 ng/kg per min or higher (Table I, Figs. 1 and 2). At higher doses, intraarterial AVP caused forearm vasodilatation in a dose-dependent fashion (Table I, Figs. 1 and 2). Forearm va- sodilatation caused by intraarterial AVP was the result of the direct effect of AVP because forearm blood flow measured simultaneously in the contralateral arm did not change (Table II).

The venous plasma AVP level associated with the maximal forearm vasoconstriction in an individual subject was $76.3 \pm 8.8 \mathrm{pg} / \mathrm{ml}$ (Fig. 3). Forearm vasodilatation was induced at the venous plasma level of $369 \pm 43 \mathrm{pg} / \mathrm{ml}$ or higher (Fig. 3). In most subjects, forearm vascular resistance returned toward the baseline level as the venous plasma AVP level increased to $>100 \mathrm{pg} / \mathrm{ml}$ (Fig. 3), which suggests that the direct vasodilatory effect was activated at this plasma AVP level. In one subject, forearm vasodilatation occurred at the venous plasma AVP level of $160 \mathrm{pg} / \mathrm{ml}$ (Fig. 3). These results raise the possibility that forearm vasodilatation observed during intravenous infusion of AVP at a high dose in previous studies $(7,8)$ may in part have resulted from the direct vasodilator effect of AVP. It has been suggested that the plasma AVP level may increase to the level of $100-500 \mathrm{pg} / \mathrm{ml}$ with severe circulatory stress (38). Thus, it appears that AVP at the pathophysiological plasma levels exerts the direct vasodilatory effect in humans. It is, however, important to note that AVP at the physiological

Table IV. Forearm Vascular Responses to Intraarterial Infusion of Isoproterenol (ISO) $(n=4)$

\begin{tabular}{|c|c|c|c|c|c|}
\hline & Control $^{*}$ & ISO (0.08) & ISO $(0.17)$ & ISO $(0.33)$ & $\begin{array}{c}P \text { value by } \\
\text { one-way ANOVA }\end{array}$ \\
\hline \multicolumn{6}{|c|}{$n g / k g$ per min } \\
\hline \multicolumn{6}{|l|}{ (1) Without calcium chloride } \\
\hline Mean blood pressure $(\mathrm{mmHg})$ & $77.9 \pm 3.3$ & $77.4 \pm 3.0$ & $77.7 \pm 2.8$ & $77.0 \pm 2.6$ & NS \\
\hline Heart rate $(b p m)$ & $63.5 \pm 1.8$ & $65.3 \pm 0.9$ & $64.5 \pm 0.7$ & $63.8 \pm 1.4$ & NS \\
\hline $\mathrm{FBF}(\mathrm{ml} / 100 \mathrm{ml}$ per min $)$ & $6.3 \pm 0.6$ & $10.6 \pm 0.5^{\ddagger}$ & $14.6 \pm 1.2^{\S}$ & $18.7 \pm 1.5^{\S}$ & $P<0.01$ \\
\hline FVR (units) & $12.8 \pm 1.1$ & $7.4 \pm 0.4^{\S}$ & $5.5 \pm 0.5^{\S}$ & $4.3 \pm 0.4^{\S}$ & $P<0.01$ \\
\hline \multicolumn{6}{|l|}{ (2) With calcium chloride } \\
\hline Mean blood pressure & $77.5 \pm 3.4$ & $76.5 \pm 3.7$ & $76.8 \pm 2.7$ & $76.8 \pm 3.9$ & NS \\
\hline Heart rate & $63.5 \pm 1.8$ & $65.0 \pm 1.5$ & $64.0 \pm 2.1$ & $64.0 \pm 2.1$ & NS \\
\hline FBF & $4.8 \pm 0.5$ & $8.4 \pm 0.8^{\S}$ & $10.4 \pm 0.8^{\S}$ & $14.1 \pm 0.7^{\S}$ & $P<0.01$ \\
\hline FVR & $17.4 \pm 2.4$ & $9.6 \pm 1.1^{\S}$ & $7.6 \pm 0.7^{\S}$ & $5.5 \pm 0.5^{\S}$ & $P<0.01$ \\
\hline
\end{tabular}

\footnotetext{
${ }^{*}$ Control, during infusion of saline (1) or during infusion of $\mathrm{CaCl}_{2}$ alone (2); ${ }^{\ddagger} P<0.05$ vs. control value; ${ }^{\S} P<0.01$ vs. control value.
} 

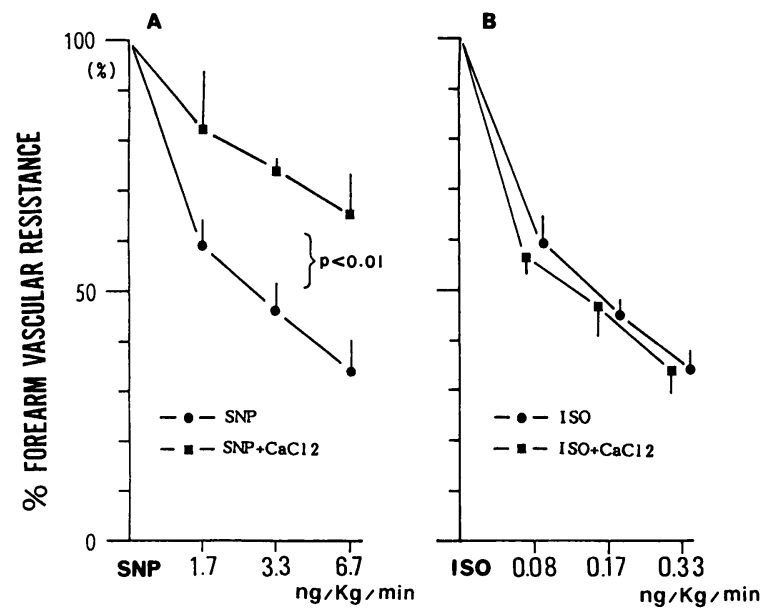

Figure 5. Percent changes in forearm vascular resistance induced by intraarterial sodium nitroprusside (SNP) $(A)$ or isoproterenol (ISO) $(B)$ at graded doses. $\bullet$, values during infusions of SNP $(n=3)$ or ISO $(n=4)$ alone; and those during simultaneous infusions of SNP $(n=3)$ or ISO $(n=4)$ and $\mathrm{CaCl}_{2}$ in squares. Simultaneous infusion of $\mathrm{CaCl}_{2}$ attenuated forearm vascular responses to SNP $(P<0.01)$ but did not alter responses to ISO (NS).

plasma levels $(<100 \mathrm{pg} / \mathrm{ml})$ caused forearm vasoconstriction (Fig. 3).

Speculation on the mechanisms involved in the direct vasodilator effect of $A V P$. Previous studies in humans and animals have suggested that AVP may stimulate several vasodilatory mechanisms, which include $(a)$ facilitated reflex inhibition of sympathetic nerve activity $(3,5,7-11,39) ;(b)$ the increased synthesis of vasodilatory prostaglandins $(12,13) ;(c)$ release of the endothelium-derived relaxant factor (EDRF) (14) and $(d)$ stimulation of the vascular $\mathrm{V} 2$ receptors $(15-17,40)$. We considered whether any of these vasodilatory mechanisms might be responsible for forearm vasodilatation caused by intraarterial AVP in humans. However, as discussed previously, it is unlikely that sympathetic withdrawal was the cause of forearm vasodilation in our subjects. Forearm vasodilation was the result of the direct vasodilatory effect but not of the systemic effect. Therefore, we now consider the possibility that any of other three mechanisms might be involved in direct vasodilatation caused by AVP.

It has been shown that AVP stimulates the synthesis of prostaglandins in kidney $(12,21-24)$ and vascular smooth muscles (25). Oliver et al. and Seino et al. have shown that intrarenal infusion of AVP caused renal vasodilatation during or immediately after cessation of infusion and that such vasodilatation was effectively blocked by indomethacin $(12,13)$. Similarly, Glänzer et al. have shown in humans that intravenous AVP increased systemic vascular resistance only after the treatment of indomethacin (6). These observations have suggested that AVP stimulates prostaglandin-mediated vasodilatory mechanisms. However, in this study, the vasodilating responses to intraarterial AVP were not altered by indomethacin at a dose of $75 \mathrm{mg} / \mathrm{d}$ for $3 \mathrm{~d}$ (Fig. 4, Table II). This dose of indomethacin has been shown to markedly potentiate the pressor response to intravenous angiotensin II in normal man (41) and to abolish the depressor effect of captopril in low renin hypertensive subjects (42). It also has been shown that this dose of indomethacin markedly suppressed the urinary excretion of prostaglandin E metabolites by $71 \%$ and inhibited platelet aggregation in man (43). These results suggest that indomethacin at a dose of $75 \mathrm{mg} / \mathrm{d}$ for $3 \mathrm{~d}$ inhibits synthesis of prostaglandins in various tissues in humans including vessels. Since indomethacin at this dose did not alter the responses evoked with intraarterial AVP, it is unlikely that AVP-induced forearm vasodilatation in our subjects was mediated by increased synthesis of prostaglandins.

Katusic et al. have reported that AVP caused endothelium-dependent vasorelaxation in the canine basilar and coronary artery in vitro (14). Thus, we need to consider the possibility that AVP-induced forearm vasodilatation might have been mediated by EDRF. However, it is not possible to examine in humans in a decisive way whether or not EDRF is involved in vasodilatation. We, therefore, asked whether AVP-induced vasodilatation was mediated by cGMP. It is known that endothelium-dependent vasorelaxation is mediated by cGMP (44-48). We examined the effect of intraarterial infusion of calcium chloride on AVP-induced forearm vasodilatation, since Fujita et al. have previously shown in humans that intraarterial calcium chloride at a rate of 0.09 $\mathrm{meq} / \mathrm{min}$ markedly attenuated cGMP-mediated vasodilatation induced by $\alpha$-human atrial natriuretic peptide (26). The results indicate that intraarterial calcium chloride inhibited AVP-induced forearm vasodilatation (Table II, Fig. 4). We also examined the effect of intraarterial calcium chloride on forearm vascular responses to intraarterial sodium nitroprusside and isoproterenol. Calcium chloride significantly attenuated nitroprusside-induced forearm vasodilatation but did not alter isoproterenol-induced vasodilatation (Tables III and IV, Fig. 5). Although the mechanisms are not clear, these results are compatible with the suggestion by Fujita et al. (26) that intraarterial calcium chloride attenuates cGMP-mediated vasodilatation but not cAMP-mediated vasodilatation. Based on these results, we speculate that AVP-induced forearm vasodilatation may be mediated by cGMP. We obviously do not know the mechanisms by which AVP may activate cGMPmediated vasodilatation. However, it might be possible that EDRF is involved, as shown in a previous study in vitro (14).

In this regard, we also measured the venous plasma level of cGMP and cAMP during intraarterial infusion of AVP. However in our subjects, venous plasma cGMP or cAMP did not change during intraarterial infusion of AVP. Venous plasma cGMP or cAMP also did not change during intraarterial infusion of sodium nitroprusside or isoproterenol, respectively. Thus, local elevations of cyclic nucleotides may not be reflected by an increase in plasma cyclic nucleotide levels. Therefore, the inability to determine an increase in plasma cyclic nucleotide levels with AVP infusion did not rule out a role of cyclic nucleotides as second messengers of AVP-mediated vasodilation. It should be noted that failure to detect the increase in cGMP during infusion of sodium nitroprusside was not due to the inadequate sensitivity of the assay system. In another study, we have observed using the same assay system as used in this study that intraarterial infusion of atrial natriuretic peptide increased venous plasma cGMP (unpublished observation). The latter finding is consistent with the results of other investigators (26). Interestingly, we have noted that intraarterial infusion of nitroglycerin did not increase venous plasma cGMP (unpublished observation). It has been suggested that atrial natriuretic peptide stimulates particulate guanylate cyclase, whereas sodium nitroprusside and nitroglycerin activate soluble guanylate cyclase (49). Thus, it ap- 
pears that plasma cGMP may increase when the formation of cGMP is catalyzed by particulate guanylate cyclase but not by soluble guanylate cyclase.

The other mechanism that we need to consider is vascular V2 receptor-mediated vasodilatation. Recent studies have shown that intravenous AVP decreased total peripheral vascular resistance after selective blockade of vasopressinergic (V1) receptors $(15-17,40)$ and that this vasodilatation was not blocked by propranolol, atropine, or indomethacin $(16,17$, 40). It also has been shown that intravenous infusion of an analogue with selective antidiuretic activity decreased total peripheral vascular resistance (40). These results suggest that AVP may cause vasodilatation by stimulating the V2 receptors. However, we consider that this mechanism was unlikely to be involved in AVP-induced forearm vasodilatation in our subjects, because AVP apparently induces V2 receptor-mediated vasodilatation only after blockade of the $\mathrm{V} 1$ receptors (15-17, 40).

In summary, intraarterial AVP caused forearm vasoconstriction at the lower and physiological plasma levels, whereas it caused forearm vasodilatation at the higher and pathophysiological plasma levels. The vasodilator effect of AVP was unlikely to be mediated by increased synthesis of prostaglandins or reflex sympathetic withdrawal. The vasodilator effect of AVP was inhibited by an increase in plasma-ionized calcium. Because increased plasma-ionized calcium attenuated nitroprusside-induced vasodilation, but not isoproterenol-induced vasodilation, it is possible that the direct vasodilatory effect of AVP may be mediated by cGMP-related mechanisms.

\section{Acknowledgments}

We thank Ms. Mieko Itoyama and Ms. Junko Yasumoto for their technical and secretarial assistance.

This study was supported by a Grant-in-Aid for General Scientific Research and by a Grant-in-Aid for Scientific Research on Priority Areas from the Ministry of Education, Science, and Culture.

\section{References}

1. Altura, B. M., and B. T. Altura. 1977. Vascular smooth muscle and neurohypophyseal hormones. Fed. Proc. 36:1853-1860.

2. Cowley, A. W., E. Monos, and A. C. Guyton. 1974. Interaction of vasopressin and the baroreceptor reflex system in the regulation of arterial blood pressure in the dog. Circ. Res. 34:505-514.

3. Montani, J. P., J. R. Liard, J. Schoun, and J. Mohring. 1980. Hemodynamic effects of exogenous and endogenous vasopressin at low plasma concentrations in conscious dogs. Circ. Res. 47:346-355.

4. Kitchin, A. H. 1957. The effect of pitressin on hand and forearm blood flow. Clin. Sci. 16:639-644.

5. Mohring, J., K. Glänzer, J. A. Maciel, R. Düsing, H. J. Kramer, R. Arbogast, and J. Koch-Weser. 1980. Greatly enhanced pressor response to antidiuretic hormone in patients with impaired cardiovascular reflexes due to idiopathic orthostatic hypotension. J. Cardiovasc. Pharmacol. 2:367-376.

6. Glänzer, K., B. Prüssing, R. Düsing, and H. J. Kramer. 1982. Hemodynamic and hormonal responses to 8-arginine-vasopressin in healthy man: effects of indomethacin. Klin. Wochenschr. 60:12341239.

7. Aylward, P. E., J. S. Floras, W. N. Leimbach, and F. M. Abboud. 1986. Effects of vasopressin on the circulation and its baroreflex control in healthy men. Circulation. 73:1145-1154.

8. Floras, J. S., P. E. Aylward, F. M. Abboud, and A. L. Mark.
1987. Inhibition of muscle sympathetic nerve activity in humans by arginine vasopressin. Hypertension (Dallas). 10:409-416.

9. Liard, J. F., O. Deriaz, M. Tschopp, and J. Schoun. 1981. Cardiovascular effects of vasopressin infused into the vertebral circulation of conscious dogs. Clin. Sci. 61:345-347.

10. Matsuguchi, H., P. G. Schmid, D. Van Orden, and A. L. Mark. 1981. Does vasopressin contribute to salt-induced hypertension in the Dahl strain? Hypertension (Dallas). 3:174-181.

11. Cowley, A. W., D. Merrill, J. Osborn, and B. J. Barber. 1984. Influence of vasopressin and angiotensin on baroreflexes in the dog. Circ. Res. 54:163-172.

12. Oliver, J. A., R. R. Sciacca, G. Le Cren, and P. J. Cannon. 1982. Modulation by prostaglandins of the renal vascular action of arginine vasopressin. Prostaglandins. 24:641-656.

13. Seino, M., K. Abe, K. Tsunoda, and K. Yoshinaga. 1985. Interaction of vasopressin and prostaglandins through calcium ion in the renal circulation. Hypertension (Dallas). 7:53-58.

14. Katusic, Z. S., J. T. Shepherd, and P. M. Vanhoutte. 1984. Vasopressin causes endothelium-dependent relaxations of the canine basilar artery. Circ. Res. 55:575-579.

15. Liard, J. F., and J. C. Spadone. 1984. Hemodynamic effects of antagonists of the vasoconstrictor action of vasopressin in conscious dogs. J. Cardiovasc. Pharmacol. 6:713-719.

16. Nyhan, D. P., P. W. Clougherty, and P. A. Murray. 1987. AVP-induced pulmonary vasodilation during specific $\mathrm{V} 1$ receptor block in conscious dogs. Am. J. Physiol. 253:H493-H499.

17. Walker, B. R. 1986. Evidence for a vasodilatory effect of vasopressin in the conscious rat. Am. J. Physiol. 251:H34-H39.

18. Hirsch A. T., V. J. Dzau, and M. A. Creager. 1987. Vasopressin is a direct vasodilator in the human forearm. Circulation. 76(Suppl. IV):0207.(Abstr.)

19. Takeshita, A., T. Imaizumi, T. Ashihara, and M. Nakamura M. 1982. Characteristics of responses to salt loading and deprivation on hypertensive subjects. Circ. Res. 51:457-464.

20. Takeshita, A., T. Imaizumi, N. Nakamura, H. Higashi, T. Sasaki, M. Nakamura, K. Kangawa, and H. Matsuo. 1987. Attenuation of reflex forearm vasoconstriction by $\alpha$-human atrial natriuretic peptide in men. Circ. Res. 61:555-559.

21. Zusman, R. M., and H. R. Keiser. 1977. Prostaglandin biosynthesis by rabbit renomedullary interstitial cells in tissue culture. Stimulation by angiotensin II, bradykinin and arginine vasopressin. J. Clin. Invest. 60:215-223.

22. Zipser, R. D., S. I. Myers, and P. Needleman. 1981. Stimulation of renal prostaglandin synthesis by the pressor activity of vasopressin. Endocrinology. 108:495-499.

23. Nadler, J., R. D. Zipser, R. Coleman, and R. Horton. 1983. Stimulation of Renal prostaglandins by pressor hormones in man: comparison of prostaglandin E2 and prostacyclin (6 keto prostaglandin F1 $\alpha$ ). J. Clin. Endocrinol. \& Metab. 56:1260-1265.

24. Kirschenbaum, M. A., A. G. Lowe, W. Trizna, and L. G. Fine. 1982. Regulation of vasopressin action by prostaglandins. J. Clin. Invest. 70:1193-1204.

25. Hassid, A., and C. Williams. 1983. Vasoconstrictor-evoked prostaglandin synthesis in cultured vascular smooth muscle. Am. J. Physiol. 245:C278-C282.

26. Fujita, T., Y. Ito, H. Noda, Y. Sato, K. Ando, K. Kangawa, and H. Matsuo. 1987. Vasodilatory actions of $\alpha$-human atrial natriuretic peptide and high Ca effects in normal man. J. Clin. Invest. 80:832840.

27. Watabe, T., K. Tanaka, M. Kumagae, S. Itoh, F. Takeda, K. Morio, M. Hasegawa, T. Horiuchi, S. Miyabe, and N. Shimizu. 1987. Hormonal responses to insulin-induced hypoglycemia in man. J. Clin. Endocrinol. \& Metab. 65:1187-1191.

28. Watabe, T., K. Tanaka, M. Kumagae, S. Itoh, M. Kogure, M. Hasegawa, T. Horiuchi, K. Morio, F. Takeda, E. Ubukata, S. Miyabe, and N. Shimizu. 1988. Role of endogenous arginine vasopressin in potentiating corticotropin-releasing hormone-stimulated corticotropin secretion in man. J. Clin. Endocrinol. \& Metab. 66:1132-1137. 
29. Honma, M., T. Satoh, J. Takezawa, and M. Ui. 1977. An ultrasensitive method for the simultaneous determination of cyclic AMP and cyclic GMP in small-volume samples from blood and tissue. Biochem. Med. 18:257-273.

30. Winer, B. J. 1971. Statistical Principles in Experimental Design. McGraw-Hill Book Co., Inc., New York. 907 pp.

31. Bie, P., A. Astrup, N. H. Secher, J. K. Sander, and J. Warberg. 1984. Hemodynamic effects of synthetic arginine vasopressin in man. Acta Physiol. Scand. 121:10A. (Abstr.)

32. Hammer, M., and K. Skagen. 1986. Effects of small changes of plasma vasopressin on subcutaneous and skeletal muscle blood flow in man. Acta Physiol. Scand. 127:67-73.

33. Hasser, E. M., J. R. Haywood, A. K. Johnson, and V. S. Bishop. 1984. The role of vasopressin and the sympathetic nervous system in the cardiovascular response to vagal cold block in the conscious dog. Circ. Res. 55:454-462.

34. Guo, G. B., P. G. Schmid, and F. M. Abboud. 1986. Sites at which vasopressin facilitates the arterial baroreflex in rabbits. Am. J. Physiol. 251:H644-H655.

35. Undesser, K. P., E. M. Hasser, J. R. Haywood, A. K. Johnson, and V. S. Bishop. 1985. Interactions of vasopressin with the area postrema in arterial baroreflex function in conscious rabbits. Circ. Res. 56:410-417.

36. Schmid, P. G., G. B. Guo, and F. M. Abboud. 1985. Different effects of vasopreen and angiotensin II on baroreflexes. Fed. Proc. 44:2388-2392.

37. Abboud, F. M., P. E. Aylward, J. S. Floras, and B. N. Gupta. 1986. Sensitization of aortic and cardiac receptors by arginine vasopressin in mammals. J. Physiol. (Lond.). 377:251-265.

38. Cowley, A. W., and J. F. Liard. 1987. Cardiovascular actions of vasopressin. In Vasopressin: Principles and Properties. D. M. Gash and G. J. Boer, editors. Plenum Press, New York. 389-433.

39. Wagner, H. N., and E. Braunwald. 1956. The pressor effect of the antidiuretic principle of the posterior pituitary in orthostatic hypotension. J. Clin. Invest. 35:1412-1418.

40. Schwartz, J., J. Liard, C. Ott, and A. W. Cowley. 1985. Hemodynamic effects of neurohypophyseal peptides with antidiuretic activity in dogs. Am. J. Physiol. 249:H1001-H1008.

41. Vierhapper, W., W. Waldhäusl, and P. Nowotny. 1981. Effect of indomethacin upon angiotensin-induced changes in blood pressure and plasma aldosterone in normal man. Eur. J. Clin. Invest. 11:85-89.

42. Abe, K. 1981. The kinins and prostaglandins in hypertension. Clin. Endocrinol. Metab. 10:577-605.

43. Rane, A., O. Oelz, J. C. Frolich, H. W. Seyberth, B. J. Sweetman, J. T. Watson, G. R. Wilkinson, and J. A. Oates. 1978. Relation between plasma concentration of indomethacin and its effect on prostaglandin synthesis and platelet aggregation in man. Clin. Pharmacol. Ther. 23:658-668.

44. Furchgott, R. F. 1983. Role of endothelium in response of vascular smooth muscle. Circ. Res. 53:557-573.

45. Rapoport, R. M., and F. Murad. 1983. Agonist-induced endothelium-dependent relaxation in rat thoracic aorta may be mediated through cyclic GMP. Circ. Res. 52:352-357.

46. Holzmann, S. 1982. Endothelium-induced relaxation by acetylcholine with larger rises in cyclic GMP in coronary arterial strips. $J$. Cyclic Nucleotide Protein Phosphorylation Res. 8:409-419.

47. Busse, R., G. Togisch, and E. Bassenge. 1985. The role of endothelium in the control of vascular tone. Basic Res. Cardiol. 80:475-490.

48. Ignarro, L. J., R. G. Harbison, K. S. Wood, and P. J. Kadowitz. 1986. Activation of purified soluble guanylate cyclase by endothelium-derived relaxing factor from intrapulmonary artery and vein: stimulation by acetylcholine, bradykinin and arachidonic acid. $J$. Pharmacol. Exp. Ther. 237:893-900.

49. Murad, F. 1986. Cyclic guanosine monophosphate as a mediator of vasodilation. J. Clin. Invest. 78:1-5. 